UDC 811.111'366.573:81’367

\author{
Junichi Toyota* \\ International Christian University \\ Tokyo, Japan
}

\title{
ON SO-CALLED ADJECTIVAL PASSIVE IN ENGLISH**
}

\begin{abstract}
This paper analyses a structure commonly known as adjectival passive. This structure has been termed adjectival based on the morphosyntactic characteristics of the participle. Surprisingly, this structure has not received its deserved attention, since previous research only focuses on the characteristics of the participle. However, one should notice that verbs used for this structure are rather limited, and they are less likely to be used in the active voice, and the whole construction, when used as the adjectival passive, denotes perception. Thus, the subject entity in the adjectival passive is predominantly human, unlike the passive voice which tends to have the inanimate entity as the grammatical subject. Such peculiarities raise a question: what is the grammatical status of the adjectival passive in English? It seems difficult to explain this construction within a common descriptive grammar of English. One possible answer to this question is posited based on a typological distinction of the alignment system and the adjectival passive is considered as a case of fluid intransitive subject. In addition, considering the diachronic changes of this construction, the adjectival passive is becoming a special category, i.e. the fluid intransitive subject system, in the verbal system in English. It can also be predicted that this may turn into the split ergative based on the lexical meaning (i.e. mental state) in the future.
\end{abstract}

Key words: adjectival passive, alignment, fluid ergativity, split ergativity, perception

* E-mail address: jtoyota@icu.ac.jp

** This paper has benefited from comments and suggestions by Donncha O'Croinin, Maireád Bates and Melisa Mustafović. None of these people are responsible for any errors of fact or method that may be found here. Abbreviations used in this paper: DAT, dative; GEN, genitive; INF, infinitive; PRES, present; VN, verbal noun. 


\section{Introduction}

One of the puzzles in the English passive concerns constructions like I am surprised at the noise. It is commonly known as adjectival passive, but this construction has the 'verbal' passive-counterpart, as in I am surprised by the noise. There are two constructions, although the same verb is used. Previous works distinguish these two constructions according to the characteristics of the past participle: in one type the participle behaves like a verb and in the other like an adjective and hence, the verbal and adjectival passive. Surprisingly, however, various previous works dealing with the passive in English do not pay deserved attention to this construction. The difference between them is much greater than just verbal or adjectival behaviours of the participle and this is what we are going to analyse in this paper. Our general aim is to highlight peculiarities of the adjectival passive and explain its historical development. We also imply a possible alternative treatment of the adjectival passive in English.

We organise this paper as follows: we first critically review the treatment of periphrastic constructions in English, which are generally discussed under the term 'passive' in various previous works. Then we concentrate on the adjectival passive, and highlight various characteristics peculiar to this construction, but not to the verbal passive. We select some eighteen verbs which frequently appear in the adjectival passive, and demonstrate the frequency of various patterns based on the corpus analysis. These patterns involve subject's animacy, actor marker, transitivity, restriction in meaning, etc. Then we analyse the historical development of the adjectival passive, pointing out the gradual shift of the preference of form among the active, the verbal passive and the adjectival passive. Finally, we propose a possible typological parallel to some languages which have split alignment system, and argue that the adjectival passive may be a case of split-intransitive subject.

Note that we employ the corpus-based analysis to demonstrate the frequency of various characteristics in the adjectival passive. The corpora used in this work are as follows: Helsinki corpus (HE, for Old English (OE), Middle English (ME) and Early Modern English (eModE)), ARCHER corpus (ARCHER, for Late Modern English (lModE)), ${ }^{1}$ London-Lund corpus (LL,

\footnotetext{
1 Note that we only extract samples of British English from ARCHER.
} 
for PDE, British, spoken), Lancaster-Oslo/Bergen corpus (LOB, for PDE, British, written).

\section{Construction I am surprised at the noise}

\subsection{Traditional view}

Within the domain of the passive voice in English, it is common practice to make a distinction between the verbal passive and the adjectival passive. One of the primal characteristics is how the past participle behaves, i.e. in the verbal passive it behaves more like verb, and in the adjectival passive, adjective. Synchronically, various tests have been proposed in the literature in order to distinguish the verbal participle from the adjectival ones, since there are some syntactic behaviours which signal the difference. They are the following: applicability of prefix; possibility of the comparative; gradability; replaceability of auxiliary be with quasi-copula, as summarised in (1). These tests are applicable to historical data, but the occurrence of past participle in certain constructions such as comparative or with adverbs such as very is quite rare in the historical data. Nevertheless, we believe that these tests can still be used for the diachronic data in spite of the infrequency.

(1) a. Affix: A negative prefix un- cannot be attached to a verb, but can be attached to adjectives derived from a verb. The acceptability of affixation to a verb in the past participle form indicates that it may not be derived from an original verb form, but from an adjectival participle.

b. Comparative: Adjectives and adverbs can occur in comparative and superlative forms and can be graded with very. Those categorised as adjectival passives can be graded, in particular can be modified by very, as in I am very surprised, He seems very disappointed, etc.

c. Quasi-copula: In the adjectival passive, but not in the verbal passive, so called quasi-copula (copula with real semantic content, often aspectual, modal or perceptional) such as look, seem, etc. can occur in the place of be. 
In addition to these three tests, there are some lesser-known characteristics. One of them is agentivity, which is often not expressed in the adjectival passive. In ModE as well as PDE, it is claimed that prepositions apart from by can be a good base to distinguish the verbal passive from the adjectival passive, as in I was surprised at the noise (adjectival passive), but I was surprised by the noise (verbal passive). Note, however, that this is not the case in the earlier period, since various prepositions are used (see Peitsara 1992; Toyota 2003). Another factor, related to agentivity, is often associated with a stative reading. The verbal passive, when it is periphrastic with auxiliary be, may be ambiguous in this respect, especially at earlier periods, since the frequency of stative reading was much higher earlier, although these constructions could express both stative and dynamic readings. When a passive clause possesses agentivity, the clause is dynamic, since agentivity and stativity cannot occur in the same clause. ${ }^{2}$ However, other auxiliaries such as weorðan 'become' in $\mathrm{OE}$ and $\mathrm{ME}$ and get in PDE, which normally express dynamic reading, do not create such ambiguity.

These tests make a clear distinction between the verbal passive and adjectival passive. However, the constructions involved in the passive are not simply verbal and adjectival, as described in detail in the following section.

\subsection{Criticism of traditional view}

The distinction of past participle into verbal and adjectival may be made clear according to the tests in (1), but one can identify some intermediate characteristics in the past participle. This type of diversity has led some scholars to the conclusion that there is no clear division between verbal and adjectival characteristics in the past participle and this relationship may be best considered as a continuum (see, for example, Haspelmath (1994), Huddleston (1984), Quirk et al (1985)). We show one such example for PDE:

2 Consider inherently stative verbs like understand, know, etc. The actor for such verbs is most likely experiencer, not agent, whereas a dynamic (i.e. punctual) verb like break normally takes agent (except for its use as labile verb). 


\begin{tabular}{|c|c|c|c|c|}
\hline Verbal & & & & Adjectival \\
\hline $\begin{array}{c}\mathrm{A} \\
{[\text { He had] }} \\
\text { taken }[i t] .\end{array}$ & \begin{tabular}{l}
\multicolumn{1}{c}{ B } \\
{$[$ He was $]$} \\
killed [by him].
\end{tabular} & $\begin{array}{l}\text { C } \\
{[\text { a rarely] heard }} \\
{[\text { work by Purcell }]}\end{array}$ & \begin{tabular}{l}
\multicolumn{1}{c}{$\mathrm{D}$} \\
{$[$ a] broken $[$ vase $]$} \\
{$[$ It seemed] broken. }
\end{tabular} & $\begin{array}{l}\text { E } \\
{[a] \text { worried }[\mathrm{man}]} \\
{[\text { He seemed }] \text { worried }}\end{array}$ \\
\hline
\end{tabular}

Figure 1. A continuum of past participle (Huddleston 1984: 324)

It seems fair to say that, as we have seen so far, there are some intermediate stages, although the distinction between the verbal and adjectival participle can be made. In addition, what is known as the adjectival passive can be turned into the verbal passive, e.g. I was surprised at the noise (adjectival passive) and I was surprised by the noise (verbal passive). The formation of the past participle here causes problems: when the adjectival participle is made from the verb surprise, the suffix is a derivational morpheme, but if it is the verbal participle, the suffix is inflectional. So the same participle can be either adjectival or verbal. So this verbal-adjectival dichotomy does not seem to be sufficient.

In addition, since previous works focus too much on the verbaladjectival distinction, they often overlook the fundamental characteristics in the passive, such as the transitivity or the causer-causee relationship. What appears to be the passive can be a non-passive construction in disguise. In previous analyses, constructions in (2) are normally considered verbal passive.

(2) a. The house is located in the city centre.

b. The box is covered with dust.

Structure-wise, these examples are identical to the verbal passive. However, what distinguishes constructions like this from the passive is the presence of outer cause or the causer-causee relationship. So once the clause is interpreted as the passive, that clause needs not only the recipient of outer cause, i.e. undergoer, but also a presence of outer cause, i.e. actor (whether it is present or absent). This makes it very difficult to interpret constructions like (2a) or (2b) as the passive, since there is no outer cause. In our view, there are three main factors to determine what the passive is, i.e. orientation, the causer-causee relationship and the tense-aspect, especially dynamic-state distinction. By analysing these characteristics, we can form the prototype of the passive (cf. Toyota 2008). 
The passive voice in general is mainly concerned with orientation (cf. Comrie 1981; DeLancey 1982; Haspelmath 1994), i.e. in the passive, the action is directed towards the undergoer, which is realised as an overt subject of the clause. However, there are superficially identical constructions with slightly different semantic features, particularly those features related to the tense-aspect system. Both the adjectival and verbal passive are undergoer-oriented, but this classifies both the adjectival and verbal passive into the same construction. Consider the adjectival passive examples in (3). These examples are all stative, which distinguishes them from the verbal passive, which is in principle dynamic.

(3) a. He was astonished at the noise.

b. I am interested in football.

c. I am satisfied with the result.

Examples in both (2) and (3) express stativity, although the stativity in (3), but not in (2), is rendered by the construction, not the lexical meaning of the participle, i.e. astonish when used in the active clause is dynamic, but once used as a past participle in (3a), stative. This type of stativity is called constructional stativity in order to distinguish it from lexical stativity, as observed in verbs like stay, remain, etc. Examples in (4) are commonly known as the verbal passive, and they differ from examples in (3) in terms of characteristics of the participle as well as aspect, i.e. (3) is stative and (4), dynamic, representing the lexical aspect of the past participle.

(4) a. The vase was broken by Sandy.

b. This new plan was proposed by the government.

The problems we can gather from (2) to (4) are as follows: i. the examples in (2) do not imply the outer cause; ii. the examples in (3) imply the outer cause, but they are stative; iii. the examples in (2) do not have active counterparts, but those in (4) certainly do and those in (3) quite possibly do, since NP in prepositional phrases can be outer cause. Facing this untidy distinction, we propose a new classificatory system. In Figure 2, the orientation of the English passive i.e. be + past participle construction and its related constructions are shown. In order to make a comparison, both stative and dynamic active clauses are also listed: 
a. Verbal passive, e.g. The window was broken by Sandy.

$$
\begin{array}{ll}
\text { window } & \text { Sandy } \\
\text { (subject) } & \text { (oblique) }
\end{array}
$$

b. Resultative, e.g. The box is covered with dust.

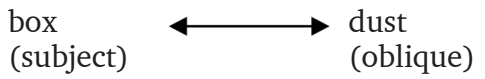

c. Adjectival passive, e.g. He was surprised at the noise.

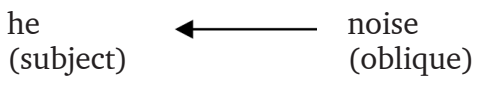

d. Active voice (stative), e.g. Everybody understands the point.

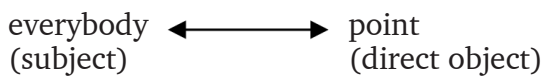

e. Active voice (dynamic), e.g. Sandy broke the window.

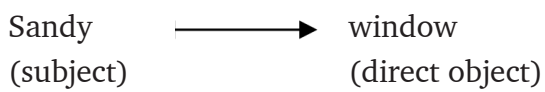

Figure 2. Orientation of the periphrastic passive and related constructions in English (based on Toyota 2008: 12)

In the verbal passive The window was broken by Sandy, the subject of the clause, undergoer, underwent some change through the event, while in the resultative The box is covered with dust, the clause expresses a state of the subject, and there is no causer-causee relationship. The main difference between them is two-fold: one is aspect, i.e. the verbal passive is dynamic, the resultative is stative, and the other is orientation, i.e. the verbal passive is undergoer-oriented, while with the resultative, no orientation is involved. In other words, the causer-causee relationship is present in the verbal passive, but absent in the resultative. However, the English passive generally has an intermediate type between the verbal and the resultative, which is the adjectival passive. The difference is that the adjectival passive is stative, like the resultative, but it still preserves the undergoer-orientation, i.e. the causer-causee relationship exists in the adjectival passive and the whole clause expresses the subject's state resulting from an event. We may note that a state created by some outer cause, as observed in the adjectival passive is known as the secondary state, as opposed to the natural state (Nedjalkov and Jaxontov 1988: 4), which is the case with the resultative, i.e. without any outer cause. 
One possible criticism of such distinction is related to the characteristics of the past participle. The distinction made so far is mainly based on the semantic characteristics. However, they do not necessarily agree with the syntactic ones. Similar conflict can be observed in the definition of transitivity: as Hopper and Thompson (1980) argue, a semantic definition of transitivity is not normally assumed. So for example, a clause with a direct object such as I like case is less transitive than a monovalent verb such as I went. However, since the passive is so closely related to high transitivity, this type of ambiguous distinction can be expected.

What we have seen in this section is a definition of the passive used throughout this work. The assumption of the active-passive counterpart and the valency reducing operation may be common practice in linguistic analysis of the passive voice, but the use of actor-undergoer distinction, instead of agent-patient, or the division of the periphrastic construction into three, the verbal passive, the adjectival passive and the resultative, may not be common practice, but they are often mentioned in this work.

\section{Adjectival passive: data analysis}

Apart from the adjectival properties of the participle and aspectual difference, there are several other characteristics of the adjectival passive which differ significantly from those of the verbal passive. Without analysing details, we can observe some obvious peculiarities of this type. They are summarised below:

(5) i. Actor markers are idiomatised.

ii. The overt subject (undergoer, not actor) is normally human.

iii.The grammatical subject is not in control of events, and is often not intentional.

iv. Most of them denote mental state or at least, can function as perceptive verbs.

Since this construction creates some consistent special meanings and characteristics, and also the relative frequency of such meanings is high, we can assume that it is forming a special type of construction in English.

In order to analyse the adjectival passive in more detail, we chose a set of verbs based on the traditional distinction, especially the ones that 
take different prepositions apart from by in the periphrastic construction, e.g. be interested in, be satisfied with, etc. (see Table 9 for details). This set contains the seventeen verbs in (6):

(6) abash, amaze, amuse, annoy, astonish, disappoint, disgust, engross, impress, infatuate, interest, inundate, obsess, please, satisfy, shock, startle, surprise

Among them, two verbs, i.e. infatuate and inundate do not occur at all in both spoken and written corpora. Some others do not occur in the spoken data, i.e. abash, amaze, annoy, disgust, engross, impress, obsess and startle. We first extract all of these verbs used as the active, the adjectival passive, the resultative, the verbal passive and others, as shown below in Table 1 . Others include the use as adjective or adverbs. The adjectival use includes both pre-modifying and post-modifying usage.

Table 1. Frequency of different types from the set of verbs in PDE

\begin{tabular}{cccc}
\hline & \multicolumn{2}{c}{ Data source } & Total \\
\hline Written & Spoken & $160(24.8 \%)$ \\
Resultative & $140(27.1 \%)$ & $20(15.8 \%)$ & $43(6.7 \%)$ \\
Adjectival passive & $230(8.3 \%)$ & $0(0 \%)$ & $329(51.1 \%)$ \\
Verbal passive & $35(6.8 \%)$ & $100(78.7 \%)$ & $37(5.8 \%)$ \\
Others & $69(13.3 \%)$ & $6(4.7 \%)$ & $75(11.6 \%)$ \\
Total & $517(100 \%)$ & $127(100 \%)$ & $644(100 \%)$ \\
\hline
\end{tabular}

It is obvious that these verbs are used as the adjectival passive most frequently, followed by active. The frequency of the adjectival passive is especially high in the spoken data. The overall occurrence of the resultative and the verbal passive is not so high. According to the data source, the spoken data contains much higher frequency of the adjectival passive, but the verbal passive is higher in the written data. The higher frequency of the verbal passive in the written data has been noted, since the passive is often associated with more formal register. For example, Givón (1979: 58-59) claims that the passive is used in English about 4\% in less-educated styles or about $18 \%$ in more-educated styles. So considering the data source, the high frequency of the adjectival passive in the spoken data should be noticed. 
There are some verbs in English (what Toyota 2009a calls passive verbs) which do not appear in the active voice at all, e.g. repute, rumour and repute, which historically did appear in the active. In this sense, the verbs shown in (6) are different and all of these verbs can be used in the active. However, note that there are three verbs disgust, engross and obsess which can be controversial, since they do not occur in the active, but only in the resultative and verbal passive as far as our data is concerned (cf. Table 22 and Table 23 in Appendix I). Among them, disgust can appear in the active, e.g. Your eating habits disgust me, but the active form of engross and obsess can be troublesome. So the passive form may be the only form possible from these two verbs. The difference between these two verbs and the passive verbs is that these two verbs have not had active counterpart in the earlier form, and they only occur in the periphrastic construction. The past participles of these verbs are more adjectival, simply having an -ed suffix in disguise.

The verbs shown in (6) are slightly different from other verbs, since although they perform the voice alternation, most of the alternation ends up in the adjectival passive. Such strong tendency indicates that these verbs form a special set of verbs in English. We analyse various semantic features of such verbs in the following sections.

\subsection{Subject's animacy}

Generally speaking, the subject of the verbal passive is known to be more inanimate, not human. This is one of the characteristics of the passive, due to the anthropocentric nature of our language. Anderson (1997: 227-228) notes that "[m]any linguists (e.g., Givón 1979: 152) have commented on the "ego/anthropocentric nature of discourse" - i.e. the fact that humans tend to speak about entities and events as they relate to the domain of human experience. Thus, in a canonical speech context, speakers and hearers are logically more likely to be interested in how the human (or otherwise "animate") referents are affected by the actions and states described in the discourse." This can be reflected in the nominal hierarchy, i.e. human beings tend to conceive the action denoted by verbs from the viewpoint of an entity higher in the hierarchy, i.e. human, or more specifically, first person. This is so, because "[s]peaker and addressee are by definition more topical or salient to the interlocutors, since they are the 
interlocutors" (Croft 2001: 315). This factor is reflected to various degrees in different languages, but in general, human entities tend to occupy the subject slot of unmarked constructions.

Bearing this tendency in mind, let us now consider the verbal passive. Since this construction is a marked one, the animacy of the subject is bound to show a different hierarchical pattern. We show the results from our corpus on PDE verbal passive in Table 2. It is clear from the table that inanimate subjects are more frequent in the verbal passive regardless of the data source, although it is slightly more frequent in the written data. So this shows that the passive is a marked construction, at least from the perspective of animacy of subject.

Table 2. Animacy of the verbal passive subject

\begin{tabular}{ccccc}
\hline Data source & Human & $\begin{array}{c}\text { Non-hum. } \\
\text { animate }\end{array}$ & Inanimate & Total \\
\hline Written & $1946(21.9 \%)$ & $51(0.6 \%)$ & $6905(77.6 \%)$ & 8902 \\
Spoken & $689(33.7 \%)$ & $17(0.8 \%)$ & $1337(65.5 \%)$ & 2043 \\
Total & $2635(24.1 \%)$ & $68(0.6 \%)$ & $8242(75.3 \%)$ & $10945(100 \%)$ \\
\hline
\end{tabular}

Now let us consider the animacy of the verbs shown in (6). First we consider the pattern in the active. The results from our data is shown in Table 3. Non-human animate hardly ever occurs, so we are basically dealing with human and inanimate entities. The result in Table 3 are somewhat surprising, since the pattern of frequency is quite similar to the one of the passive shown in Table 2. Since this is the active voice, the subject is supposed to be more human, but these verbs do not show such a pattern. In turn, the result of the passive and the resultative is shown in Table 4. We take the combination of the adjectival passive and the verbal passive, since they are both undergoer-oriented. With this set of verbs, the undergoer-orientation seems to indicate that the subject is predominantly human rather than inanimate. It is not characteristic of the passive, since the subject is supposed to be non-human (cf. Table 2). 
Table 3. Animacy of the subject in the active

\begin{tabular}{ccccc}
\hline Data source & Human & $\begin{array}{c}\text { Non-hum. } \\
\text { animate }\end{array}$ & Inanimate & Total \\
\hline Written & $60(42.9 \%)$ & $3(2.1 \%)$ & $77(55.0 \%)$ & 140 \\
Spoken & $1(5.0 \%)$ & 0 & $19(95.0 \%)$ & 20 \\
Total & $61(38.1 \%)$ & $3(1.9 \%)$ & $96(60.0 \%)$ & $160(100 \%)$ \\
\hline
\end{tabular}

Table 4. Animacy of the subject in the adjectival and verbal passive

\begin{tabular}{ccccc}
\hline Data source & Human & $\begin{array}{c}\text { Non-hum. } \\
\text { animate }\end{array}$ & Inanimate & Total \\
\hline Written & $244(92.1 \%)$ & 0 & $21(7.9 \%)$ & 265 \\
Spoken & $98(97.0 \%)$ & 0 & $3(3.0 \%)$ & 101 \\
Total & $342(93.4 \%)$ & 0 & $24(6.6 \%)$ & $366(100 \%)$ \\
\hline
\end{tabular}

So at first sight, this set of verbs seems to show the marked pattern in the active. Then is it really marked? As far as the anthropocentric nature of our language is concerned, the speaker tends to use the first person more frequently and the third person less frequently, since the third person is not typically involved in the discourse. If this set of verbs appears in the verbal/adjectival passive like other verbs in English, then they are at least supposed to show higher frequency in the third person. Consider the result of data in Table 5. As far as our data are concerned, the third person is more common. This creates somewhat untidy distinction: the passive/ adjectival passive exhibits a generally unmarked distinction of animacy, but in terms of person, it is marked. Such untidy distinction may be a reason for ambiguity in this construction.

Table 5. Distinction in the personal subject in the adjectival and verbal passive

\begin{tabular}{ccccc}
\hline Data source & $1^{\text {st }}$ person & $2^{\text {nd }}$ person & $3^{\text {rd }}$ person & Total \\
\hline Written & $74(30.3 \%)$ & $11(4.5 \%)$ & $159(65.2 \%)$ & 244 \\
Spoken & $46(46.9 \%)$ & $13(13.3 \%)$ & $39(39.8 \%)$ & 98 \\
Total & $120(35.1 \%)$ & $24(7.0 \%)$ & $198(57.9 \%)$ & $342(100 \%)$ \\
\hline
\end{tabular}




\subsection{Actor marker and agentivity of actor}

We concentrated on the undergoer in the pervious section, but in this section, we analyse the actor. In the passive/adjectival passive, the actor is often not overly expressed. If it is, the frequency is generally known as about $20-30 \%$ of all occurrence of the passive (cf. Toyota 2008: 100). The actor, when expressed in the oblique case, is normally headed by a preposition by, which may make it less obvious that this is an outer cause, since by itself does not obviously indicate SOURCE of outer cause as other prepositions like from or of can. This nature of by has been noticed by some scholars. Svartvik (1966: 105), for example, points out that ambiguous usage of byphrase between an outer cause and a non-outer cause in examples like Oil will be replaced by coal. He terms such use of the by-phrase a janus-agent, which he defines as "constituents which permit two different active clause transformations according to whether they are interpreted as agents [i.e. actor] or adjuncts [i.e. non-actor]."

Our results also confirm that the actor phrase is not expressed frequently in the verbal passive, as shown in Table 6. Notice the difference in the frequency according to the data source. The written data has higher frequency of the overtly expressed actor. Now we examine the results in the set of verbs used as the adjectival and verbal passive. As Table 7 shows, the overall frequency of actor phrase is not so different from the one of the verbal passive, but the spoken data has higher frequency in comparison with the verbal passive in general. Table 7 just shows the results of an overall presence of actor, but as we stated in (5i) earlier, this set of verbs has idiomatised actor markers according to each verb, such as surprised at, interested in, etc. When the distinction between more conventionalised by and other idiomatised prepositions is made, we gain the result shown in Table 8. It is obvious that these verbs are closely associated with certain prepositions.

Table 6. Presence/absence of actor in the prepositional phrase in the verbal passive

\begin{tabular}{cccc}
\hline Data source & Actor present & Actor absent & total \\
\hline Written & $2623(29.5 \%)$ & $6279(70.5 \%)$ & 8902 \\
Spoken & $365(17.9 \%)$ & $1678(82.1 \%)$ & 2043 \\
Total & $2988(27.3 \%)$ & $7957(72.7 \%)$ & $10945(100 \%)$ \\
\hline
\end{tabular}


Table 7. Presence/absence of actor in the prepositional phrase in the adjectival and verbal passive

\begin{tabular}{cccc}
\hline Data source & Actor present & Actor absent & total \\
\hline Written & $147(28.4 \%)$ & $370(71.6 \%)$ & 517 \\
Spoken & $49(38.6 \%)$ & $78(61.4 \%)$ & 127 \\
Total & $196(30.4 \%)$ & $448(69.6 \%)$ & $644(100 \%)$ \\
\hline
\end{tabular}

Table 8. Frequency of the idiomatised prepositions as actor marker

\begin{tabular}{cccc}
\hline Data source & Preposition by & $\begin{array}{l}\text { Idiomatised } \\
\text { prepositions }\end{array}$ & Total \\
\hline Written & $26(17.7 \%)$ & $121(82.3 \%)$ & 147 \\
Spoken & $2(4.1 \%)$ & $47(95.9 \%)$ & 49 \\
Total & $28(14.3 \%)$ & $168(85.7 \%)$ & $187(100 \%)$ \\
\hline
\end{tabular}

The distinction in the prepositions often functions as a marker for the verbal passive and the adjectival passive in traditional terms. So according to a previously common distinction, the idiomatised prepositions can indicate that the construction is the adjectival passive, while by indicates the verbal passive. However, this distinction is not accurate and we are bound to find exceptions, even if we retain the traditional terms. Moreover, we do not retain the traditional distinction and have proposed a new classification. Our distinction is only concerned with the presence/absence of outer cause, regardless of its overt expression. Let us take some examples: obsess is often associated with the preposition with or about, but by can often occur with it. In the following example, (7) is allegedly an instance of the verbal passive, while (8) and (9) instantiate the resultative.

(7) The authors of both the majority and the minority reports of the Committee of Inquiry into the Rating of Site Values (1952) seem to have been obsessed by the idea of annual rental value, for both reports speak of "the annual site value" (i.e. the yearly rent which the site might be expected to yield if let at the valuation date upon a perpetual tenure). (LOB E28 157-162)

(8) During the last few years of his life there is ample evidence that Graham's mind was obsessed with religious mania and that he was becoming, eventually, a victim of his own tomfoolery. (LOB G56 144-146) 
(9) If there is what the same paper has called a 'British obsession about soldiers in politics', then many parts of the world have been giving us plenty to be obsessed about. (LOB G74 4951)

According to the traditional grammar, the presence of by guarantees the status of verbal passive, but this is questionable in (7). The by-phrase is certainly an outer cause, but it is not an agent. Also consider the instance in (10): obsess itself expresses dynamic aspect, and if it is used in the verbal passive, the whole clause is supposed to be dynamic. However, in spite of the presence of by, the following instance is stative (notice the presence of still, which is a typical case of resultative, cf. Nedjalkov and Jaxontov 1988). This makes (10) a case of adjectival passive, not verbal passive. So by as an actor marker does not guarantee the status of the verbal passive. The opposite distinction can happen: when the preposition is not by, the clause can still be dynamic. Consider the case of annoy in (11). This example, in spite of the preposition, expresses dynamic aspect. However, annoy can take other prepositions such as at, and in the case of (12), the clause is stative and it is a case of the resultative.

(10) And Mr. Coward is still obsessed by the immensely important fact that other people do not dress exactly as he does. (LOB A19 23-24)

(11) The Danes are annoyed with British farmers for fighting against Danish competition. They say that our farmers do not seem to understand the meaning of free trade. (LOB B04 222225)

(12) Gino wiped his face and head with an old handkerchief. It had stopped drizzling, and he was annoyed at having allowed himself to be soaked. (LOB N29 64-67)

Such instances cast a serious doubt about the distinction of a construction based on the choice of prepositions. We list various types of prepositions associated with each verb in Table 9. There seem to be some patterns, and at and with seem to be common. However, how come this set of verbs can accept variety of prepositions, like about, by or with in the case of obsess? 
Table 9. Set of verbs and their idiomatised prepositions

\begin{tabular}{cccc}
\hline Verbs & Prepositions & Verbs & Prepositions \\
\hline abash & at, by & infatuate & by, with \\
amaze & at, by & interest & by, in \\
amuse & by, with & inundate & by, with \\
annoy & at, by, with & obsess & about, by, with \\
astonish & at, by, with & please & at, by, with \\
disappoint & about, at, by, in, & satisfy & by, with \\
& with & & \\
disgust & at, by, with & shock & at, by \\
engross & by, in & startle & at, by \\
impress & by, in, with & surprise & at, by \\
\hline
\end{tabular}

The prepositions as actor markers have received little attention, except for Peitsara (1992) and Toyota (2003, 2008), along with some other works like Visser (1963-73), which list various possible choices of prepositions in the history of English. It is common to express the actor as a source of outer cause, and if a language uses prepositions to indicate actor, 'from' and 'of' are most commonly used, as in, for instance, other Germanic languages (cf. Toyota 2009b). In this sense, the use of by as actor marker is unique. Due to its lexical meaning, it is plausible to claim that this preposition creates 'proximity' of outer cause (cf. Toyota 2003). In this sense, the use of at or with is understandable, since they also describe the location of object. The difference, if there is any, may lie in the specificity: for example, at can specify the cause in detail, while with seems to lack such specificity, at least to the degree at does. Consider verbs that take these prepositions. Verbs expressing 'surprise' or 'shock' do not take with, except for astonish, probably because these verbs require the specific mention of the onset of outer cause. Those verbs associated with with need not specify such onset. Then how can one account for such variations? The significance of such prepositions can be attributed to the subjective viewpoints. In PDE, the choice of prepositions seems to be a collocation, closely attached to the lexical meaning of verb, but there are certain choices and such choice of the prepositions can be attributed to the subjective view of the speaker/ writer. This means that whether specificity is indicated overtly or not is up to the speaker/writer.

Another argument related to the choice of prepositions is the low degree of agentivity: As we have seen in Table 3, this set of verbs, when 
they appear in the active, occur with inanimate subjects. Such pattern of animacy is reflected in the animacy of actors, as indicated in Table 10. This means that the majority of outer cause cannot be agentive: the clause is not transitive, in a traditional sense of transferring energy from one participant to another. This is also reflected in the stativity of the construction. So the construction is concerned with the description of the state. This also interacts with the subjective viewpoint, since the subjective viewpoint allows the speaker to choose different prepositions based on his/her own way of viewing the state. This creates variations like disappointed about, at, by, in and with.

Table 10. Animacy of NP in the prepositional phrase in the adjectival and verbal passive

\begin{tabular}{ccccc}
\hline Data source & Human & $\begin{array}{c}\text { Non-hum. } \\
\text { animate }\end{array}$ & Inanimate & Total \\
\hline Written & $20(14.5 \%)$ & 0 & $118(85.5 \%)$ & 138 \\
Spoken & $5(10.2 \%)$ & 0 & $44(89.8 \%)$ & 49 \\
Total & $25(13.4 \%)$ & 0 & $162(86.6 \%)$ & 187 \\
\hline
\end{tabular}

\subsection{Stativity}

The adjectival passive, as we have defined it, is a construction which implies the outer cause and the clause is stative, not dynamic. We have seen that such a distinction can be controversial, and this is so due to the characteristics of the participle: once the inherently stative verbs are involved in the passivisation, the overall interpretation of the clause is stative, but this is due to the participle. Scholars like Givón (1990: 571-572) claim that one of the functions of the passive (i.e. our verbal passive) is stativisation. However, such claim is highly questionable, as Haspelmath (1990: 38) argues that "there is no direct relation between passives and states".

We have so far distinguished several properties that make a participle more verbal or more adjectival. According to such distinction, when a participle is adjectival, it tends to create stativity, and when verbal dynamicity. However, this is not always the case and there is one particular set of verbs which behave differently: those verbs that create stativity on their own, such as perception verbs see, hear, understand, etc., behave like verbal participle in the passive, but the interpretation of the whole clause 
is still stative. This proves that stativity in the passive can interestingly be expressed in terms of both syntax and semantics. The syntactic dichotomy is 'verbal passive vs. adjectival passive/resultative', where the verbal passive is dynamic and the adjectival passive/resultative is stative. The semantic dichotomy is 'process vs. state', where the process is dynamic and state, needless to say, stative. In order to make this statement clearer, consider the example in (13). The whole clause is stative, while the structure is like that of the verbal passive, since the past participle does not behave like an adjective. This example cannot accept various tests introduced in (1): prefix un-, *He was unknown by many people; comparative, *He was more known by many people; quasi-copula, *He seemed known by many people. In discussing the data and the analysis of examples in Section 3, we explained that we treat such cases as verbal passive in spite of their stativity. However, issues concerning the stative verbs are not restricted to the case like (13): some of the stative verbs can be passivised, and others cannot. For example, consider the examples in (14). Some stative verbs like resemble do not require outer cause, i.e. they denote a natural state as opposed to secondary state. Thus, passivisation is not possible with some stative verbs if they cannot imply actor. Our distinction of resultative is based on the stativity and the absence of actor. So the semantic condition of examples like (14) is identical with the one of resultative, but (14b) is yet ungrammatical.

(13) He was known by many people.

(14) a. This book can be kept for three weeks.

b. *This boy is resembled by his father.

Such cases show that stative verbs behave somewhat differently in the passive and we analyse their internal semantic characteristics: first, we look at the thematic roles. We have been using the terms actor and undergoer so far, but we want to pay attention to a finer distinction, such as agent and patient. The stereotypical passive is said to possess a patient entity in the subject slot and an agent entity in the oblique phrase. Verbs like believe, hear, know, like, see and understand generally involve experiencer as subject and theme as an object. Although it is difficult to draw a line between theme and patient, the object involved in the stative verbs bears a much lower degree of affectedness or it does not undergo the change at all. This reveals that patient is less likely to be involved. 
When the set of verbs in (6) are concerned, the clause is stative but the main verb, when used in the active, denotes dynamic aspect, as shown in (15) to (20).

(15) They are, however, bold in the use of rhyme to a degree that would astonish Mr. Ogden Nash. (LOB C12 119-120)

(16) Some leading communists confide that the system is now too liberal to achieve quickly enough the kind of results that will impress the children and young people. (LOB E22 76-78)

(17) There is a widespread belief that the ruling Tories are becoming more reactionary, trying to please their Right Wing more than their Left or centre supporters. (LOB B20 158-160)

(18) Whether such an apparatus can be incorporated in a reactor circuit in a manner that will satisfy safety requirements will need further study. (LOB J01 172-174)

(19) It grew even more acute e acute when a four-man commission led by Mr Justice Devlin, sent out to investigate the reasons for the upheaval, produced a long report which shocked everyone - except, as it seemed later, the government. (LOB F05 112-116)

(20) I watched him because I was always fascinated by the way he looked when you tried to surprise him. (LOB N06 99-100)

So the difference between the adjectival passive and the verbal passive with stative verbs is that the stative aspect in the adjectival passive is derived from the construction itself, not from the main verb. Also, as we have seen in the previous section, the choice of prepositions does not guarantee the stative-dynamic distinction of the clause: recall the earlier example with obsess in (10) and annoy in (11). The traditional distinction based on the preposition does not always guarantee the aspectual distinction. Such an instance also indicates that it is the construction, not the main verb or prepositions, that determines the aspectual distinction. 


\subsection{Transitivity}

As we have seen in Section 2.2, the passive involves the force-dynamic alternation or the causer-causee alternation, which is in essence equal to transitivity alternation. The term transitivity is normally used very loosely in linguistic theory, and at least two types can be identified. One type is semantic transitivity, and the other, syntactic transitivity. The semantic one is concerned with the transfer of energy from one entity (actor) to another (undergoer). The syntactic one is only concerned with whether the direct object is present (transitive) or absent (intransitive). Alternatively, transitivity can be viewed in continuum, as proposed in Lakoff (1977) or Hopper and Thompson (1980). What we are concerned with here is the outer cause, so we are concerned more with the semantic transitivity than the syntactic one. According to this type of transitivity, when a lexical verb is transitive, such as verbs of creation or destruction (cf. Kozinsky 1980; Testelec 1998), the passivisation is more easily done. Kittilä (2002: 23) rightly points out this correlation of the passive and transitivity as follows:

Passivization makes it in many (but not all) cases possible to separate transitive clauses from less transitive ones, since ... only clauses conceived of as somehow transitive are to be passivized in many languages. The acceptability of passivization correlates to some extent with transitivity: the more transitive a clause is, the more readily it can be passivised (see, for example, Lehmann 1991: 224f and Rice 1987).

Transitivity here is used in a sense of Hopper and Thompson (1980), i.e. the semantic transitivity, concerned with the transfer of energy itself from one entity to another regardless of structural patterns. What is commonly assumed by this term seems to be related to the syntactic definition, concerning the number of arguments, e.g. intransitive verbs are monovalent (such as go in I go to town) and transitive verbs are divalent (such as break in He broke the cup) or trivalent (such as give in He gave her a present).

Hopper and Thompson (1980) go further on the semantic aspect of transitivity, claiming that a transitive construction often serves as a topical construction, i.e. interlocutors are familiar with the information carried in the transitive clause, while an intransitive clause functions as a focus 
construction, introducing a new piece of information. These two versions of definitions (syntactic and semantic) do not always get along well with each other. For example, in terms of syntactic definition, examples like I like cakes is transitive, since it involves two arguments I and cakes. However, in the semantic definition, it is not so transitive, since the clause does not imply much transfer of action or event, but it is more likely to denote the mental state of the subject. Such complication is explicitly expressed in Hopper and Thompson (1980). They provide ten parameters of transitivity as shown in Table 11. So when a clause possesses more parameters, it is more transitive.

Table 11. Parameters of transitivity, adopted from Hopper and Thompson (1980: 252)

\begin{tabular}{lll}
\hline & High & Low \\
\hline a. Participants & 2 or more participant, agent & 1 participant \\
& and object & \\
b. Kinesis & action & non-action \\
c. Aspect & telic & Atelic \\
d. Punctuality & punctual & non-punctual \\
e. Volitionality & volitional & non-volitional \\
f. Affirmative & affirmative & negative \\
g. Mode & realis & irrealis \\
h. Agency & agent high in potency & agent low in potency \\
i. Affectedness of object & object totally affected & object not affected \\
j. Individuation of object & object highly individuated & object non-individuated \\
\hline
\end{tabular}

According to the parameters in Table 11, clauses like She left are more transitive than I like cakes, since the first example possesses more parameters than the second one. The difference is summarised in Table 12, but we add one more example, He broke the window, which is unambiguously transitive in both syntactic and semantic definition. So what is commonly considered intransitive, She left, can be considered more transitive than what is known as transitive I like cakes. So based on the parameters like this, it may be better to consider transitivity in terms of relative transitivity or in a sense of gradience. 
Table 12. Parameters of transitivity, applied to three examples

\begin{tabular}{lccc}
\hline & She left. & I like cakes. & He broke the window. \\
\hline a. Participants & - & + & + \\
b. Kinesis & + & - & + \\
c. Apsect & + & - & + \\
d. Punctuality & + & - & + \\
e. Volitionality & + & - & + \\
f. Affirmative & + & + & + \\
g. Mode & + & + & + \\
h. Agency & + & - & + \\
i. Affectedness of object & - & - & + \\
j. Individuation of object & - & - & + \\
\hline
\end{tabular}

Keys: $+=$ parameter high; $-=$ parameter low

So when a syntactic transitive clause like I like cakes is passivised, it can create some difficulty, since it is semantically intransitive, i.e. it is difficult to have a right context for it to appear in the passive Cakes are liked by me. This is because the clause is less agentive, non-punctual and the object is not much affected, and thus, intransitive. Clauses involving the set of verbs shown in (6) can be syntactically transitive in the active, but semantically, they are less transitive, since the action cannot be agentive or volitional. This is clearly shown by the fact that the actor is often inanimate (cf. Table 4 and Table 5). We illustrate one instance from the set of verbs in (6), i.e. The noise surprised me and its verbal passive and adjectival passive counterpart I was surprised by the noise and I was surprised at the noise, respectively, and analyse this sentence according to the ten parameters shown in Table 11. The result is shown in Table 13.

Table 13. Parameters of transitivity, applied to The noise surprised me

\begin{tabular}{lccc}
\hline & $\begin{array}{c}\text { The noise } \\
\text { surprised me. }\end{array}$ & $\begin{array}{c}\text { I was surprised } \\
\text { by the noise. }\end{array}$ & $\begin{array}{c}\text { I was surprised } \\
\text { at the noise. }\end{array}$ \\
\hline a. Participants & + & - & - \\
b. Kinesis & + & + & - \\
c. Aspect & + & + & - \\
d. Punctuality & + & + & - \\
e. Volitionality & - & - & -
\end{tabular}




\begin{tabular}{llll} 
f. Affirmative & + & + & + \\
g. Mode & + & + & + \\
h. Agency & - & - & - \\
i. Affectedness of object & + & - & - \\
j. Individuation of object & + & - & - \\
\hline
\end{tabular}

Keys: + = parameter high; $-=$ parameter low

The active clause seems to be more transitive (scoring eight high parameters), but the adjectival passive seems to be intransitive (scoring two high parameters). The verbal passive seems to be intermediate, scoring five high parameters. So it seems that once a verb is used in the adjectival passive, it becomes less transitive, thus this process can be considered de-transitivisation. Stativity gained from the passivisation of the verbs in (6) is, thus, only a by-product of the de-transitivisation, but not the main function. In addition, the adjectival passive is in a sense similar to the perfective construction, differing only in the orientation, i.e. the clause is mainly concerned with the current state of the undergoer resulting from the earlier action. However, it has to be distinguished from the perfective passive, as in PDE The window has been broken by small children, where the overt marking of perfective aspect is grammatically present. The adjectival passive we are analysing could express such aspect without an overt marking.

\subsection{Restrictions in meaning}

In relation to the stativity created in the resultative, the change in the meaning has to be distinguished. The set of verbs in (6), when used in the active clause, express actions of astonishing, pleasing, surprising, etc. However, once they are used in the periphrastic construction, they seem to express the mental state, in a sense of 'in a state of being astonished, pleased, surprised, etc.' This case must be distinguished from the passivisation of perception verbs. The mental states created by the perception verbs are due to the lexical meanings of the main verb, in addition to the stativity reflecting the aspectual nature of past participles. So by the process of passivisation, the verbs in (6) create extra meanings, i.e. mental state, and the function of stativisation. 
The difference in meanings can also be supported by the fact that there are instances of quasi-copula. The overall frequency of the quasicopula in our data is shown in Table 14. The overall occurrence seems to be insignificant, but among quasi-copulas found in the adjectival passive, there is a clear tendency that perception verbs are more frequently used: quasi-copula involves perception verbs such as seem, look, etc., but it also involves others, such as become, get, which are often known as inchoative verbs. The frequency of perception verbs among the quasi-copulas is shown in Table 15, followed by examples, representing each possible quasi-copula in our data.

Table 14. Frequency of quasi-copula as auxiliary

\begin{tabular}{cccc}
\hline Data source & Quasi-copula & Auxiliary be & Total \\
\hline Written & $32(6.2 \%)$ & $485(93.8 \%)$ & $517(100 \%)$ \\
Spoken & $3(2.4 \%)$ & $124(97.6 \%)$ & $127(100 \%)$ \\
Total & $35(5.4 \%)$ & $609(94.6 \%)$ & $644(100 \%)$ \\
\hline
\end{tabular}

Table 15. Frequency of perception verbs in quasi-copula

\begin{tabular}{cccc}
\hline Data source & Perception verbs & Inchoative verbs & Total \\
\hline Written & $29(90.6 \%)$ & $3(9.4 \%)$ & $32(100 \%)$ \\
Spoken & $0(0 \%)$ & $3(100 \%)$ & $3(100 \%)$ \\
Total & $29(82.9 \%)$ & $6(17.1 \%)$ & $35(100 \%)$ \\
\hline
\end{tabular}

appear (3 instances)

(21) Above all, a mother should appear pleased about her daughter's physical changes because it indicates approaching maturity, and this is something, the mother must imply, to be looked forward to, not dreaded. (LOB F17 146-149)

feel (7 instances)

(22) What a night on which to P04 74 die, she thought, trying to feel amused. (LOB P04 73-74)

look (14 instances)

(23) Everyone looked impressed and Mother said proudly, "Julia's going to be clever. (LOB K25 51-52) 
seem (4 instances)

(24) He seemed particularly interested in Wedgwood beakers, a Decca record-player and Cooper's Oxford Marmalade. (LOB R04 37-38)

sound (1 instance)

(25) It is only occasionally that he gives the impression of not wanting to sound too impressed, as, for example, when he mentions in passing the numerous puerilites [puerile] in Lawrence's daily life and in many of his books. (LOB C12 174-177)

The use of perception verbs as auxiliaries indicates that the adjectival passive as a whole is often related to the perception, but the overall frequency is not so high. This is probably due to the overlap of meaning, i.e. the meaning of perception is also obvious in the adjectival passive itself, and the perception verbs are used to specify what type of perception is involved, e.g. visual perception, audible perception, etc. Perception is in general a subjective matter, i.e. it is concerned with how a speaker/ writer describes an event/situation from his/her own point of view. This is also reflected in the high frequency of the human subject in the adjectival passive (cf. Table 4 and Table 5), although the third person seems to be more common than the first person. However, the verbal passive is more commonly expressed with the inanimate subject, and the high frequency of human subject is a peculiarity of the adjectival passive.

The meaning of mental state created by the adjectival passive also explains the high frequency of human subject, since it is human beings that perceive outer stimuli and expressing mental state is more likely to be based on the subjective view point.

\subsection{Synchronic peculiarities of adjectival passive}

As stated in (5), the adjectival passive has peculiarities, such as idiomatised actor markers, animacy of subject as human, and the whole clause expresses the mental state. In addition to this, we have seen that the adjectival passive achieves de-transitivisaiton, and the stativity is a constructional one, not lexical one. We summarise these characteristics in Table 16. 
Table 16. Summary of characteristics of adjectival passive

\begin{tabular}{|c|c|}
\hline & Characteristics \\
\hline Subject's animacy & $\begin{array}{l}\text { Subject tends to be human, which is identical to the unmarked } \\
\text { active clause. }\end{array}$ \\
\hline Actor marker & $\begin{array}{l}\text { Various prepositions can be used, unlike the verbal passive where } \\
\text { by is normally associated with the construction. Also, the choice of } \\
\text { prepositions seems to be subjective. }\end{array}$ \\
\hline Stativity & $\begin{array}{l}\text { Stativity comes form the construction, not from the lexical meaning } \\
\text { of the verb, since verbs used in the adjectival passive on their own } \\
\text { expresses dynamic aspect. }\end{array}$ \\
\hline Transitivity & $\begin{array}{l}\text { The adjectival passive performs the function of de-transitivisation, } \\
\text { which means that the clause is intransitive, both syntactically and } \\
\text { semantically. }\end{array}$ \\
\hline Perception verbs & $\begin{array}{l}\text { There is a restriction in the meaning of the verb, and the adjectival } \\
\text { passive as a whole functions like perception verbs and expresses the } \\
\text { meaning of mental state. }\end{array}$ \\
\hline
\end{tabular}

Having analysed the synchronic characteristics of the adjectival passive, we move onto its diachronic development in the rest of the paper and suggest why this construction emerged and what type of construction it is typologically.

\section{Adjectival passive in diachronic perspective}

The origin of the passive is considered as stative/adjectival constructions. As discussed at length in Toyota (2008: 15-28), earlier stative constructions are most likely to have expressed perfective aspect. Due to various changes apart from the passive, the earlier perfective construction became the passive (see Toyota 2009c for a detailed argument). However, when it comes to the adjectival passive, we can find features peculiar only to this construction, but not to the verbal passive or the resultative. What is peculiar is that this construction almost always expresses the meanings of mental state. Recall the verbs listed in (6): they all express the mental state once used in the adjectival passive, although their active counterparts may not necessarily do so, e.g. I am shocked expresses the mental state, but The sad news shocked me expresses the action itself.

It is worth mentioning the general development of the perception verbs in English first. Earlier perception verbs had a different case marking 
system from an unmarked construction, and the experiencer was typically expressed in dative, and the cause in either nomaintive or genitive. This type of verbs is also known as impersonal verbs; there are about 40 verbs classified as impersonal verbs and earlier English borrowed some such verbs from Old French and Scandinavian languages. (Bauer 1998: 112). See Pocheptsov (1997) for a list of them. The example (26) illustrates a typical instance of an impersonal verb.

$$
\begin{aligned}
& \text { Mæg pæs ponne ofpyncan Jeodne Heaðobeardna } \\
& \text { may that.GEN then displease.INF lord.DAT Heathobards.GEN } \\
& \text {... ponne ... } \\
& \text { when }
\end{aligned}
$$

'It may displease the lord of the Heathobards ... when ...' (Beo 2032)

This set of verbs became 'personalised' by the lME period. Impersonal verbs may appear to be unrelated to the adjectival passive, especially at the morphosyntactic level. However, they play a significant role at the morphosemantic level, especially due to the fact that they are normally perception verbs.

Verbs expressing the mental state seem to be treated slightly differently from other verbs in the history of English, and the chronology of impersonal verbs and the verbs in (6) used in the adjectival passive can indicate some pattern: impersonal verbs disappeared in lME/eModE, and the aspectual change in the periphrastic construction (i.e. the emergence of verbal passive) happened during ME (cf. Toyota 2008). Without the aspectual change, the adjectival passive was not created. So it seems that the mental state has been expressed in marked constructions, first by impersonal verbs (up to $\mathrm{ME} / \mathrm{eModE}$ ) and then by the adjectival passive (from ME onwards). As shown in Table 1, about $50 \%$ of verbs shown in (6) appear as the adjectival passive, and about $25 \%$ as active in PDE. So there is an obvious tendency for these verbs to appear in the adjectival passive in PDE. Historically, we can observe a gradual shift in such tendency. In Table 17, we show the same distinction shown in Table 1 in historical perspectives. We also reproduce the overall results of PDE without distinction of data source for convenience. We omit the OE data, since there are only a couple of examples found in the corpus. Such paucity is also found in the ME data. 
Table 17. Frequency of different types from the set of verbs in (6) from ME to PDE

\begin{tabular}{ccccc}
\hline & ME & eModE & lModE & PDE \\
\hline Active & $19(76.0 \%)$ & $139(68.8 \%)$ & $276(44.0 \%)$ & $160(24.8 \%)$ \\
Resultative & $0(0 \%)$ & $0(0 \%)$ & $4(0.6 \%)$ & $43(6.7 \%)$ \\
Adj. passive & $4(16.0 \%)$ & $55(27.2 \%)$ & $270(42.9 \%)$ & $329(51.1 \%)$ \\
Verbal passive & $0(0 \%)$ & $1(0.5 \%)$ & $14(2.2 \%)$ & $37(5.8 \%)$ \\
Others & $2(8.0 \%)$ & $7(3.5 \%)$ & $65(10.3 \%)$ & $75(11.6 \%)$ \\
Total & $25(100 \%)$ & $202(100 \%)$ & $629(100 \%)$ & $644(100 \%)$ \\
\hline
\end{tabular}

There are a couple of points to be noted from Table 17: first, the active became less frequent from 1 ModE onwards and the adjectival passive became the most frequent construction instead. The adjectival passive has been used, but it was not so frequent earlier. The second point is that the other constructions like the verbal passive gradually increase their frequency, but their overall frequency and the rate of increase may not be so significant.

Apart from the difference in the construction of each construction, we look at some semantic features of each construction, particularly issues relating to the animacy and subject's control over the event or state. We have already seen the subject's animacy in the adjectival and verbal passive in Table 4. Here, we show the results historically, for each period, in Tables 18 to 21 . We omit the occurrence of others, since they are either adjective or adverb and no subject is involved:

Table 18. Subject's animacy in PDE

\begin{tabular}{|c|c|c|c|c|}
\hline \multirow[t]{2}{*}{ Constructions } & \multicolumn{3}{|c|}{ Subject animacy } & \multirow[t]{2}{*}{ Total } \\
\hline & Human & $\begin{array}{l}\text { Non-human } \\
\text { animate }\end{array}$ & Inanimate & \\
\hline Active & $61(38.1 \%)$ & $3(1.9 \%)$ & $96(60.0 \%)$ & $160(100 \%)$ \\
\hline Resultative & $41(95.3 \%)$ & $0(0 \%)$ & $2(4.7 \%)$ & $43(100 \%)$ \\
\hline $\begin{array}{l}\text { Adjectival } \\
\text { passive }\end{array}$ & $311(94.5 \%)$ & $3(0.9 \%)$ & $15(4.6 \%)$ & $329(100 \%)$ \\
\hline Verbal passive & $31(83.8 \%)$ & $0(0 \%)$ & $6(16.2 \%)$ & $37(100 \%)$ \\
\hline Total & $509(89.5 \%)$ & $4(0.7 \%)$ & $56(9.8 \%)$ & $569(100 \%)$ \\
\hline
\end{tabular}


Table 19. Subject's animacy in lModE

\begin{tabular}{ccccc}
\hline Constructions & \multicolumn{3}{c}{ Subject animacy } & Total \\
\cline { 2 - 4 } & Human & $\begin{array}{c}\text { Non-human } \\
\text { animate }\end{array}$ & Inanimate & \\
\hline Active & $162(58.7 \%)$ & $1(0.4 \%)$ & $113(40.9 \%)$ & $276(100 \%)$ \\
Resultative & $2(50.0 \%)$ & $2(50.0 \%)$ & $0(0 \%)$ & $4(100 \%)$ \\
Adjectival & $243(90.0 \%)$ & $0(0 \%)$ & $27(10.0 \%)$ & $270(100 \%)$ \\
passive & & $0(0 \%)$ & $4(28.6 \%)$ & $14(100 \%)$ \\
Verbal passive & $10(71.4 \%)$ & $3(0.5 \%)$ & $144(25.5 \%)$ & $564(100 \%)$ \\
Total & $417(74.0 \%)$ & & & \\
\hline
\end{tabular}

Table 20. Subject's animacy in eModE

\begin{tabular}{ccccc}
\hline Constructions & \multicolumn{3}{c}{ Subject animacy } & Total \\
\cline { 2 - 4 } & Human & $\begin{array}{c}\text { Non-human } \\
\text { animate }\end{array}$ & Inanimate & \\
\hline Active & $56(39.2 \%)$ & $0(0 \%)$ & $87(60.8 \%)$ & $143(100 \%)$ \\
Resultative & $0(0 \%)$ & $0(0 \%)$ & $0(0 \%)$ & $0(0 \%)$ \\
Adjectival & $51(100 \%)$ & $0(0 \%)$ & $0(0 \%)$ & $51(100 \%)$ \\
passive & & $0(0 \%)$ & $0(0 \%)$ & $1(100 \%)$ \\
Verbal passive & $1(100 \%)$ & $0(0 \%)$ & $5(2.6 \%)$ & $195(100 \%)$ \\
Total & $190(97.4 \%)$ & & & \\
\hline
\end{tabular}

Table 21. Subject's animacy in ME

\begin{tabular}{ccccc}
\hline Constructions & \multicolumn{3}{c}{ Subject animacy } & Total \\
\cline { 2 - 4 } & Human & $\begin{array}{c}\text { Non-human } \\
\text { animate }\end{array}$ & Inanimate & \\
\hline Active & $7(36.8 \%)$ & $0(0 \%)$ & $12(63.2 \%)$ & $19(100 \%)$ \\
Resultative & $0(0 \%)$ & $0(0 \%)$ & $0(0 \%)$ & $0(0 \%)$ \\
Adjectival & $4(100 \%)$ & $0(0 \%)$ & $0(0 \%)$ & $4(100 \%)$ \\
passive & & $0(0 \%)$ & $0(0 \%)$ & $0(0 \%)$ \\
Verbal passive & $0(0 \%)$ & $0(0 \%)$ & $5(21.7 \%)$ & $23(100 \%)$ \\
Total & $18(78.3 \%)$ & 0
\end{tabular}

The striking result is that the frequency of subject animacy has not changed much over periods of time: the active clause has more inanimate subject, while the adjectival passive favours human subject. As already mentioned earlier in Section 3.1, human beings tend to describe the event from the viewpoint of human, i.e. ego-centric or anthropocentric viewpoint, and 
such tendency can be altered in marked constructions like the adjectival or verbal passive. However, the difference in this set of verbs from others is that the human subject is more frequent in a marked construction and an unmarked construction, active, tends to have an inanimate subject. So it is clear by now that the verbs listed in (6) even historically show a rather abnormal pattern as far as subject's animacy is concerned.

From historical perspectives, it has been argued that there are some factors for the preservation of such abnormal grammatical characteristics, stativity in particular. Stativeness can be singled out, since it is cognitively more salient than its counterpart, dynamicity, and there are several pieces of evidence to indicate this. We do not go into much detail, but it has been argued that child language acquisition, noun-verb distinction and perhaps language genesis can give us some clues. In all these cases, more stative constructions appear first and they form a base for more complex, dynamic constructions. See Toyota (2006) for further arguments and examples.

So it is quite probable that the inherent stativity in the structural/ lexical semantics in the adjectival passive delayed the shift in frequency from active to the adjectival passive in the set of verbs shown in (6) and this is why these verbs still possess abnormal animacy patterns. This claim could be extended to the impersonal verbs, which resisted the unmarked case marking pattern till ME/eModE.

\section{Future of adjectival passive and fluid intransitive subject}

Historically, perception verbs were singled out and treated slightly differently from other verbs. Similarly, it can be observed cross-linguistically that a particular set of verbs are often treated differently. This is basically considered in terms of alignment, i.e. the pattern of treatment of subjects and direct objects, referring to the distribution of morphological markers or of syntactic, semantic or morphological characteristics. Many languages can be clearly classified as nominative-accusative alignment or ergative alignment and there are some which have active alignment, but there are also languages that show a mixture of them based on various conditions. Such mixture is often known as split in alignment. Dixon (1994) assumes two such subtypes, split-S and fluid-S system (the capital S here represents the subject of monovalent verb). According to the split-S system, what appears to be ergative system can be found in particular constructions, 
restricted according to tense, aspect, nature of subject NP such as nominal hierarchy, etc. (cf. Dixon 1994: 83-108). So what appears to be a parallel to the English periphrastic passive in, say, Celtic languages as in (27) is in fact restricted to the perfective aspect and it cannot appear independent of such an aspectual restriction. This was also the case in the verbal passive in earlier English, e.g. the OE passive was concerned more with the aspect than with the grammatical voice, and its undergoer-orientation was structurally stranded. So such a construction is better considered a type of split-S (for a similar argument on the Irish periphrastic constructions, see Orr 1984, 1989, Toyota 2009c. A case of Slavic languages can be found in Toyota and Mustafović 2006).

\section{Irish \\ (27) Tá mo t-obair na bhaile criochnaiegh be.PRES my work the home finish.VN 'My home work is finished/I have finished my homework.'}

Another type, fluid-S system, is similar to the split-S, but the split is not set rigidly and some flexibility between the split and non-split alignment can be found, as summarised below (Dixon 1994: 78-79), and schematised in Figure $3:^{3}$

There is a fascinating group of languages which has syntactically based marking for transitive verbs - always marking $\mathrm{A}$ and $\mathrm{O}$ in the same way for a given verb - but uses semantically based marking for intransitive verbs - with direct marking reflecting the semantics of each particular instance of use. ... In a fluid$\mathrm{S}$ language the A-type and O-type markings are allocated to intransitive clauses semantically, with each intransitive verb having the possibility of either choice [between $S_{a}$ and $S_{o}$, J.T.], depending on the semantics of each particular context of use. In practice, some verbs refer to activities that are always likely to be controlled and these are always likely to be marked as $S_{a}$; other verbs refer to activities or states that are likely never to be controlled and these are always likely to be shown as $S_{0}$. But there will be many verbs in a middle region, referring to activities

${ }_{3}$ Note the following terminologies: A corresponds to transitive subject; O, transitive object; $\mathrm{S}_{\mathrm{a}}$, intransitive subject marked like A; $\mathrm{S}_{\mathrm{o}}$, intransitive subject marked like $\mathrm{O}$. 
where there can be control or lack of control, and these may accordingly be marked either as $\mathrm{S}_{\mathrm{a}}$ or $\mathrm{S}_{\mathrm{o}}$.

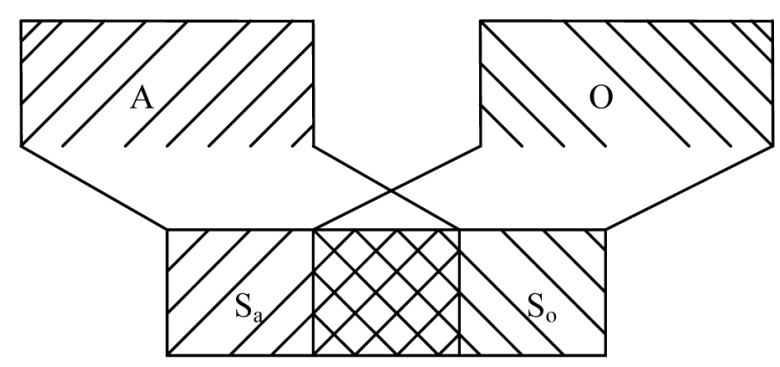

Figure 3. Schematic representation of fluid-S system, adapted from Dixon (1994: 79)

As the schema shows, there is a certain degree of overlap in the middle of lower part of the figure and this overlap is often determined by the particular meaning that a verb can produce. At first sight, one may be confused whether fluid-S is actually identical with active alignment. The stereotypical active alignment consists of both sides of lower part in the figure, i.e. $S_{a}$ and $S_{o}$, which is decided based on whether intransitive subject is capable of initiating an action on its own or not. When a language belongs to fluid-S system, some intransitive verbs can behave like either $\mathrm{S}_{\text {a }}$ or $\mathrm{S}_{\mathrm{o}}$, depending on the context. For example, Holinsky (1987) analysed 303 intransitive verbs in Tsova-Tush (Caucasian), and found out that thirty one verbs appear only with $S_{0}$, referring to uncontrollable state, such as 'be hungry', 'tremble', etc., and seventy eight verbs only with $S_{a}$, referring to controllable activities, such as 'walk', 'talk', 'think', etc. The remainder can take both $\mathrm{S}_{\mathrm{a}}$ or $\mathrm{S}_{\mathrm{o}}$ marking. For instance, a single verb root can be interpreted as 'slip' when used with $\mathrm{S}_{\mathrm{o}}$, and as 'slide' with $\mathrm{S}_{\mathrm{a}}$ (Holinsky 1987: 125). In active alignment, this type of flexibility does not happen. However, as Dixon (1994: 83) rightly claims, "the syntactically based marking and semantically based marking types are idealisations, with many languages combining features of each. Nevertheless, most languages with a split conditioned by the semantic nature of the verb are either clearly fluid-S or else clearly split-S [active alignment]. It is not uncommon for a split-S [active alignment] to have a handful of verbs that can take either $\mathrm{S}_{\mathrm{a}}$ or $\mathrm{S}_{\mathrm{o}}$ marking, but this is often a case of lexicalisation". 
Historical development of the adjectival passive proves that the verbs listed in (6) certainly prefer the adjectival passive in PDE, but there still is a possibility for them to appear in the active. When they are analysed in terms of transitivity, they are intransitive in the adjectival passive, but arguably transitive in the active. It is 'arguable' since some of them may not satisfy the semantic aspect of transitivity. Nevertheless, it is possible to claim that these verbs form the fluid-S system in English based on a choice of lexical meanings, i.e. the undergoer-orientation only appears when the verbs denote mental state. However, the problem of such analysis is the developmental path: Indo-European languages used to have active alignment earlier (cf. Lehmann 1989, 1997, 2002; Gamkrelidze and Ivanov 1995), as early as Proto-Indo-European. Some of them remained much later into modern languages, and there are some residues in earlier English (cf. Toyota 2009b). The fluid-S system develops as a result of overlap between syntactic marking and semantic function in the course of language change. The adjectival passive in English was created as a result of the change in the be-perfective, but it is only indirectly related to the change in alignment, since the development of perfective construction is related to the alignment change (cf. Toyota 2009b), i.e. a topic-focus system, for example, has changed dramatically in English from a topicprominent language to a subject-prominent language (cf. Li and Thompson 1976), and this made the environment where the earlier be-perfective was used change and formed the ground for the verbal passive to develop (cf. Toyota 2009b).

Analysing the current state and historical change of the adjectival passive (cf. Table 17), the active form decreases dramatically and the adjectival passive gains much popularity. This indicates that the verbs in (6) are clearly forming a different alignment, although allowing a different type at the same time. Judging from the current state of the English verbal system typologically, the adjectival passive in English is actually a case of fluid-S, although they may form a different alignment system, particularly ergative one, in the future, considering the direction of change observed so far. The fluid-S may be a peculiarity of English, since, as Dixon (1994: 146 fn.3) claims, English has a fluid transitivity, meaning that the transitivity is not strictly applied to verbs, and some class of verbs, such as labile verbs, can be both syntactically and semantically intransitive/transitive. This may be related to the viewpoint of the speaker, i.e. a speaker may consider one action as transitive, but others may not. Similarly, Wierzbicka 
(1996: 410) claims that "we should constantly remind ourselves that the number of syntactic core arguments depends not on the number of entities in the situation referred to, but on the manner in which the situation is conceptualized by the speaker, and that one cannot speak, for example, of a 'transitive action' or 'intransitive action', because the same action may be viewed as 'transitive' or 'intransitive' depending on the point of view." This may explain the difference in, for example, spray-load verbs. Also, when it comes to the adjectival passive, the choice of actor markers can reflect the speaker's viewpoint. Labile verbs or spray-load verbs are often considered under the term 'middle voice' in English, but the adjectival verbs clearly differ from them. So it is possible to claim that the adjectival passive forms a special category on its own in the English grammar.

\section{Conclusion}

We have analysed the adjectival passive in this paper. We first argued that the general dichotomy in relation to the periphrastic passive in English, i.e. the verbal and adjectival passive, is not as accurate as it should be, and it is often the case that a third construction, resultative, is considered as a type of verbal passive, but it should be separated. In the distinction, the transitivity and the orientation play an important role.

Synchronically, there are a number of peculiarities which can distinguish the adjectival passive from the verbal passive. This can be summarised in (28).

(28) i. The adjectival passive can have prepositions other than by to indicate actor.

ii. The subject animacy has an unusual pattern, i.e. inanimate tends to be subject in active, and human in the adjectival passive.

iii. The construction is stative, similar to the origin of the passive, i.e. be-perfect. However, the stativity is created structurally, i.e. this is a constructional stativity, not a lexical one.

iv. Markedness in terms of mental state: earlier impersonal verbs, which had marked subject marking, expressed the mental state, and in PDE, the adjectival passive expresses such meanings. 
Such peculiarities raise a question: what is the status of the adjectival passive in English? It does not seem that this construction can be accounted for within a common descriptive grammar of English. We posit one possible answer to this question, and this is to consider the adjectival passive as a case of fluid intransitive subject. Diachronically, the eighteen verbs we analysed tend to appear increasingly in the adjectival passive, rather than in the active. This suggests the adjectival passive is becoming a special category, i.e. the fluid intransitive subject system, in the verbal system in English. Based on the direction of changes so far (cf. Table 17), we presume that the fluidity in the current system is becoming less flexible and the adjectival passive may appear to be a case of split ergative based on the lexical meaning (i.e. mental state) in the future. However, this fluidity does not seem to disappear completely and the fluid system may persist.

\section{References}

Anderson, G. D. S. (1997). On "animacy maximization" in Fox (Mesquakie). Journal of American Linguistics 63: 227-247.

Bauer, B. L. M. (1998). Impersonal verbs in Italic: their development from an Indo-European perspective. Journal of Indo-European Studies 26: 91-120.

Comrie, B. (1981). Aspect and voice: some reflections on perfect and passive. In: Tedeschi, P. J. \& A. Zaenen (eds.) Syntax and Semantics (vol. 4): Tense and Aspect. New York: Academic Press. 65-78.

Croft, W. (2001). Radical Construction Grammar: Syntactic Theory in Typological Perspective. Oxford: Oxford University Press.

DeLancey, S. (1982). Aspect, transitivity and viewpoint. In: Hopper, P. J. (ed.) Tense-Aspect: Between Semantics and Pragmatics. Amsterdam: John Benjamins: 167-183.

Dixon, R. M. W. (1994). Ergativity. Cambridge: Cambridge University Press.

Gamkrelidze, T. V. \& V. V. Ivanov (1995). Indo-European and Indo-Europeans: a Reconstruction and Historical Analysis of a Proto-language and Protoculture (part 1): text. (English version by Johanna Nichols). Berlin: Mouton de Gruyter.

Givón, T. (1979). On Understanding Grammar. New York: Academic Press. 
Givón, T. (1990). Syntax: A Functional-Typological Introduction (vol.2). Amsterdam: John Benjamins.

Haspelmath, M. (1990). Grammaticalization of the passive morphology. Study of Language 14: 25-72.

Haspelmath, M. (1994). Passive participle across languages. In: Fox, B. \& P. J. Hopper (eds.) Voice: Form and Function. Amsterdam: John Benjamins. 151-177.

Holinsky, D. A. (1987). The case of the intransitive subject in Tsova-Tush (Batsbi). Lingua 71: 103-132.

Hopper, P. J. \& S. A. Thompson (1980). Transitivity in grammar and discourse. Language 56: 251-339.

Huddleston, R. D. (1984). Introduction to the Grammar of English. Cambridge: Cambridge University Press.

Kittilä, S. (2002). Transitivity: Towards a Comprehensive Typology. Turku, Finland: University of Turku Press.

Kozinsky, I. Š. (1980). Nekotorye grammatičeskie universalii v podsistemax vyraženija sub'ektno-ob'ektnyx otnošenij. Doctoral dissertation, MGU Moscow.

Lakoff, G. (1977). Linguistic gestalts. Chicago Linguistic Society 13: 236287.

Lehmann, C. (1991). Predicate classes and participation. In: Seiler, H. \& W. Premper (eds.) Partizipation: das sprachliche Erfassen von Sachwerhalten. Tübingen: Gunter Narr. 183-239.

Lehmann, W. P. (1989). Problems in Proto-Indo-European grammar: residues from pre-Indo-European active structure. General Linguistics 29: 228-246.

Lehmann, W. P. (1997). Active language characteristics in Pre-IndoEuropean and Pre-Afro-Asiatic. General Linguistics 35: 57-79.

Lehmann, W. P. (1999). Towards a history of early Indo-European. Diachornica 16: 67-95.

Lehmann, W. P. (2002). Pre-Indo-European. Journal of Indo-European Studies Monograph 41.

Li, C. N. and S. A. Thompson (1976): Subject and topic: a new typology of language. In: Li, C. N. (ed.). Subject and Topic. New York: Academic Press. 457-489.

Nedjalkov, V. P. \& S. Je. Jaxontov (1988). The typology of resultative constructions. In: Nedjalkov, V. P. (ed.). Typology of Resultative Constructions. Amsterdam: John Benjamins. 3-62. 
Orr, R. (1984). An embolic ergative construction in Irish? General Linguistics 24: 38-45.

Orr, R. (1989). A Russo-Goidelic syntactic parallel: $U$ nego svoja izba postavlena/Tá sé déanta agam. General Linguistics 29: 1-21.

Peitsara, K. (1992). On the development of the by-agent in English. In: Rissanen, M., O. Ihalainen, T. Nevalainen \& I. Taavitsainen (eds.) History of Englishes: New Methods and Interpretations in Historical Linguistics. Berlin: Mouton de Gruyter. 379-400.

Pocheptsov, G. G. (1997). Quasi-impersonal verbs in Old and Middle English. In: Fišiak, J. (ed.) Studies in Middle English Linguistics. Berlin: Mouton de Gruyter. 469-488.

Quirk, R., S. Greenbaum, G. Leech \& J. Svartvik (1985). A Comprehensive Grammar of the English Language. London: Longman.

Rice, S. (1987). Toward a cognitive model of transitivity. Doctoral dissertation, University of California, San Diego.

Svartvik, J. (1966). On Voice in the English Verb. The Hague: Mouton.

Toyota, J. (2003). Preposition by in the English passive revised. In: Aijmer, K. \& B. Olinder (eds.) Proceedings from the $8^{\text {th }}$ Nordic conference on English studies. Göteborg: Acta Universitatis Gothoburgensis. 107-120.

Toyota, J. (2006). Persistency in evolution of language. Cognitive Systems 7, 63-80.

Toyota, J. (2008). Diachronic Changes in the English Passive. Basingstoke: Palgrave.

Toyota, J. (2009a). Fossilisation of passive in English: Analysis of passive verbs. English Studies 90, 476-497.

Toyota, J. (2009b). Passive as an indicator of alignment change: in terms of transitivity. Groninger Arbeiten zur germanistischen Linguistik, spezial issue The passive in Germanic languages, 41-52.

Toyota, J. (2009c). Passive as a tense-aspectual construction revisited: a case of Germanic languages. Groninger Arbeiten zur germanistischen Linguistik, special issue The passive in Germanic languages, 200-214.

Visser, F. Th. (1963-73). An Historical Syntax of the English Language. (4 vols.) Leiden: E. J. Brill.

Wierzbicka, A. (1996). Semantics: Primes and Universals. Oxford: Oxford University Press.

Received: 15 July, 2013

Accepted for publication: 25 October, 2013 
Јунићи Тојота

\title{
О ТАКОЗВАНОМ ПРИДЕВСКОМ ПАСИВУ У ЕНГЛЕСКОМ
}

\begin{abstract}
Сажетак
У раду се анализира структура енглеског језика која се уобичајено назива $n p u$ девски пасив. Назив придевски пасив заснива се на морфосинтаксичким особинама партиципа. Изненађујуће је што посматрана структура до сада није добила пажњу какву заслужује, будући да се претходна истраживања усредсређују само на особине партиципа. Међутим, треба уочити да су глаголи који се у овој структури користе прилично ограничени, да се ређе користе у активним конструкцијама, као и да читава конструкција употребљена као придевски пасив означава перцепцију. Отуда је ентитет који је субјекат у придевском пасиву доминантно људски, за разлику од пасива иначе, где се у улози граматичког субјекта јављају претежно неживи ентитети. Такве посебности намећу питање граматичког статуса придевског пасива у енглеском језику. Посматрану конструкцију тешко је објаснити на основу уобичајене дескриптивне граматике енглеског језика. У раду се нуди могући одговор на дато питање на основу типолошке дистинкције система поретка субјекат-објекат и придевски пасив се посматра као случај флуидног непрелазног субјекта. Поврх тога, у светлу дијахронијске промене, придевски пасив постаје засебна категорија у глаголском систему енглеског језика - систем флуидног непрелазног објекта. Такође се може предвидети да ће се та конструкција на основу лексичког значења (ментално стање) у будућности претворити у раздељени ергатив.
\end{abstract}

Кључне речи: придевски пасив, поредак субјекат-објекат, флуидна ергативност, раздељена ергативност, перцепција 